\section{0 året for den første trykte litauiske bog}

\author{
Af Dr. Dalia Barauskaite Mikkelsen
}

$\mathrm{I}$ år for 450 år siden udkom den første trykte bog på litauisk, Katekismens ord (Catechismusa prasty szadei...). Årsdagens betydning fremgår af, at den er med på UNESCO's kalender over store kulturbegivenheder i 1997 og at den litauiske regering har erklæret året 1997 som året for den første litauiske bog. Katekismens ord blev udgivet $\mathrm{i}$ Königsberg (det nuværende Kaliningrad) i $\varnothing$ stpreussen. Det er i dag ikke muligt at finde trykkeriet, hvor også den første katekismus på oldpreussisk (1545) samt flere værker på de lokale sprog blev trykt. Trykkeriet blev, ligesom mange andre udtryk for en fortidig blomstrende kultur i Königsberg og hele Østpreussen, ødelagt af krige, pest og tidens tand, som også udslettede de lokale oldpreussere, litauerne i Østpreussen samt deres besejrere tyskerne og gav plads til nye folkeslag og skikke. Alligevel er tiden ikke i stand til at udslette det spor, den første trykte litauiske bog efterlod.

\section{Hvorfor er netop Katekismens} ord så dyrebar for litauerne? Litauens tradition for litteratur i bredere forstand starter jo i slutningen af det 14. århundrede med historiske krøniker skrevet på gammelt hviderussisk. Som bevis på, at der fandtes ældre tekster på litauisk, findes en håndskreven tekst, en oversættelse af "Fader Vor", "Ave Maria!" og "Credo" til litauisk, fra midten eller slutningen af det 15. århundrede.

Trykning af bøger på forskellige sprog begyndte i Litauen et par årtier før Katekismens ord udkom. I perioden fra 1522, hvor den hviderussiske humanist Francysk Skoryna startede et trykkeri i Vilnius - det ældste i hele det område, som senere omfattede Sovjetunion, - til 1551, året, som afslutter perioden for såkaldte palæotyper, blev der trykt en hel del bøger på de forskellige sprog, der taltes i Storfyrstendømmet Litauen. Den første litauiske bog er én blandt de mange litauiske palæotyper.

Rent umiddelbart ser bogen ud som et beskedent religiøst værk på 78 sider, format på $18 \times 11 \mathrm{~cm}$. Den består af en latinsk dedikation i vers, et forord på latin, et langt forord på litauisk i vers, en litauisk $\mathrm{ABC}$, en katekismus på litauisk samt nogle litauiske protestantiske salmer med noder. Af de oprindelige ca. 200-300 eksemplarer kender vi i vore dage kun to, det ene findes i Torun Universitetsbibliotek i Polen, og det andet opbevares sammen med andre sjældne og dyrebare bøger i Vilnius Universitetsbibliotek.

Bogen er dog langt mere end dette. Dens struktur og tekster er som et spejlbillede af grundtanken og ånden i hele renæssancen i Litauen, et udtryk for forfatterens store personlighed. Omstændighederne ved bogens udgivelse er en koncentration af turbulente politiske, nationale, religiøse og kulturelle begivenheder $\mathrm{i}$ Østpreussen og Storfyrstedømmet Litauen i det 16. århundrede.

Bogen har ikke kun åbnet døren til litteratur på litauisk, som indtil 2. verdenskrig ikke alene skabtes i Litauen, men også i nabolandet Østpreussen. Bogen repræsenterer fælles vilkår for den litauiske kultur og litteratur, der i Litauen, som i andre central- og østeuropæiske nationalstater, havde en lidt anden betydning end $\mathrm{i}$ 


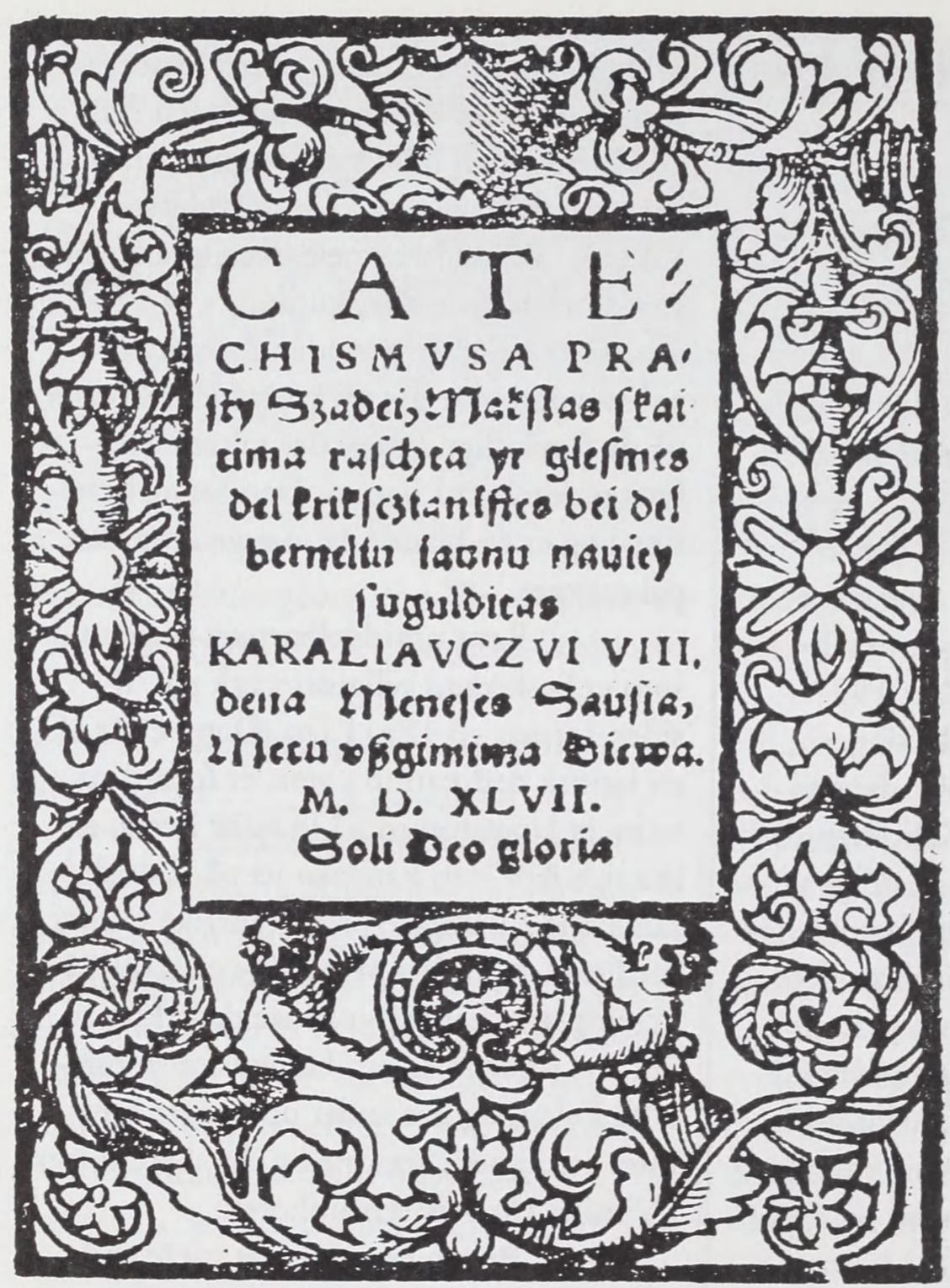

Titelbladet fra den forste tryke litauiske bog, Katekismens ord, fra 1547.

de vesteuropæiske lande. Derfor er det ikke mærkeligt, at bogens ånd kan spores i Litauens kultur i dag og i de seneste to århundreder.

Bogens politiske og kulturelle kontekst A t de første bøger på litauisk ikke blev udgivet i selve Litauen, kan både se mærkeligt og konsekvent ud. Mærkeligt, fordi der i Litauen, som i det 16. århundrede oplevede en kulturel blomstring, blev skrevet og udgivet mange bøger: religiøse værker, politiske og historiske traktater, statslige administrative skrifter, digte osv. Det kendetegnende ved de fleste bøger var deres polemiske karakter, hvilket ikke kun skyldtes polemik mellem den katolske kirke og den udbredende reformation.

Storfyrstendømmet Litauen var både før og senere et multietnisk land, hvor mange forskellige kulturer og religioner levede side om side. I det 16 . århundrede vrimlede hovedstaden Vilnius med trykkerier, hvor protestanter udgav bøger vendt mod katolikker, hvor man i russiskortodokse værker gjorde grin med både protestanter og katolikker, og hvor disse 
udgav polemiske skrifter mod russiskortodokse, og hvor arianere kritiserede calvinister i disses kirker. Litaueren Abraomas Kulvietis (Abraham Culvensis), Martin Luthers og P. Melanchtons elev, stiftede i 1539 en højere skole i Vilnius, hvor han propaganderede for den lutherske tro, og dronning Bona Sforza, kongens og storfyrstens kone og militant katolik, støttede skolen. I nogle af de mange kirker i Vilnius proklamerede calvinister deres tro samtidig med at katolikker $\mathrm{i}$ andre kirker fordømte reformationen, og ved siden af de kristnes kirker, omgivet af polemik, blomstrede jødernes synagoger og tatarernes moskeer.

Der herskede dog en fredelig sameksistens blandt de mange etniske grupper, kulturer og religioner i Storfyrstendømmet Litauen, og der var hverken blodige folkedrab eller ødelæggelser, som man kender fra bl.a. en række vesteuropæiske lande i det 16. århundrede. Uoverensstemmelser udtrykte sig gennem udgivelse af polemiske bøger, stiftelse af universiteter og opførelse af kirker. Reformationen i Litauen var heller ikke den rystelse, man kendte fra nabolandene mod nord og vest, men mere en "tidens mode", der især vandt udbredelse blandt de litauiske storadelsfamilier. Lige så hurtigt som disse overgik til reformationen - især midt i det 16. århundrede - konverterede de tilbage til katolicismen et par årtier senere. Den religiøse tolerance, der herskede i Storfyrstendømmet Litauen, galdt også dem: tidligere reformerte blev inddraget $\mathrm{i}$ arbejdet ved forskellige statsinstitutioner, hvor russiskortodokse allerede længe havde arbejdet side om side med katolikkerne.

Den litauiske reformation har uden tvivl vakt tanken om "samfundet" og "det sociale" og inspireret landets kulturliv.
På den anden side har den ikke tilført Litauen det nationale, som det skete i de nordlige og vestlige nabolande. Ved at anvende reformationen til egne politiske formål overså de litauiske adelsmænd det litauiske sprogs betydning. I det 16. århundrede taltes litauisk næsten udelukkende af samfundets laveste lag - bønderne og de fattige byborgere. Litauisk var for adelsmændene altså plebejernes sprog. Måske fremkaldte dette sprog for dem også billedet af det gamle hedenske Litauen, som de kristne lande havde foragtet og forfulgt. Litauen var jo det sidste land i Europa, som afskaffede den hedenske tro, - så sent som i 1387, - men denne tros relikter har i lang tid vækket afsky hos både den katolske og protestantiske kirke.

"I skal forlade alle de nisser og trolde, Alle de djævle og gudinder:

For de gudinder kan ikke give jer noget godt,

De vil bare føre jer i evig fortabelse"

Således opfordres folk til at forlade den hedenske tro i den første litauiske bog. Dette viser, at den gamle tro var levende blandt litauerne så sent som i det 16. århundrede. Også senere. Og det var bestemt ikke det billede af landet, de litauiske adelsmænd ønskede at vise Europa. Litauens overgang til kristendommen var en betingelse for at få plads i "det fine Europa", hvis forbillede var Polen. Via Polen blev Litauen døbt, og det polske sprog blev snart udbredt ikke kun i kirker, men også i Storfyrstens hof og blandt adelsfamilier. 
Ordensstaten bliver et verdsligt hertugdømme

I nitiativtagere til udarbejdelse og udgivelse af de første bøger på litauisk var myndighederne i det østpreussiske hertugdømme. Hovedstaden Königsberg blev ikke kun center for bøger på tysk, litauisk og oldpreussisk. Her kom mange bøger på nabolandenes sprog til verden: på polsk, lettisk, estisk og livisk.

Dette skyldtes ikke kun reformationen, som snart blev udbredt i Østpreussen. Grundtanken bag reformationen her var ikke at give de undertrykte lokale sprog samme rettigheder, som det tyske sprog havde. Efter at have udgivet tre oldpreussiske katekismer $(1545,1550$ og 1560), tog myndighederne sig f.eks. ikke længere af dette sprog og oldpreusserne, et folkeslag, som ikke havde nogen rettigheder i Den Tyske Orden og som på forhånd var dømt til at forsvinde fra deres land, selvom det oldpreussiske sprog (beslægtet med litauisk og lettisk) først definitivt forsvandt i det 18. århundrede. Den primære opgave ved reformationen som statens religion var at forstærke landets nye status og gennem den nye tro at gøre den lokale befolkning loyal over for nye myndigheder. Indtil begyndelsen af det 18 . århundrede var to tredjedele af landets befolkning stadigvæk oldlpreussere og litauere, som levede et for deres tyske herrer uforståeligt liv. "Hvor ukultiveret og mørk vores folks levevis er, folk, der hverken kender til fromhed eller den kristelige tro (...). Mange dyrker stadigvæk hedenske ritualer for øjnene af andre: nogle forguder træer og floder, andre forguder snoge eller noget andet (...)" (fra M. Mazvydas's brev til præster).

I det 16. århundrede mistede Den Tyske Orden sin tidligere betydning.
Alle nabolandene var allerede kristne, og den tidligere Ordensstat blev desuden svækket af indre strid. Ordenens stormester Albrecht af Hohenzollern (14901568) smed munkedragten, erklærede staten som det verdslige hertugdømme Preussen og aflagde i 1525 ed overfor Litauens Storfyrste og Polens Konge som hertug af Preussen. Efter at være blevet fordømt af Paven og truet af den tyske kejser, var hertugen meget interesseret $i$ at befæste sin egen og landets nye status. Til dette formål benyttede han reformationen. Derudover indså han den historiske chance, som reformationen tilbød hans land: at øve indflydelse på den tidligere Tyske Ordens arvefjende - Litauen, hvor især den vestlige del i århundreder har været en landplint, som forhindrede Ordenen $i$ at slå sig fast langs hele Østerøøens østlige kystområde og herved at forene sig med Livonien (Den Tyske Orden i lettiske, liviske og estiske områder). Det sprog, man talte i Litauen, var det samme, som blev talt af de litauere, der boede i Hertugdømmet Preussens nordøstlige del.

Hertug Albrechts politiske instinkt bød ham denne gang at følge en anden taktik end krig overfor de historiske fjender, nemlig at påvirke Litauen med den lutherske tro og bøger på det nationale sprog.

Første skridt var en undervisningsreform i hertugdømmet. I 1542 etablerede Albrecht et såkaldt partikular i Königsberg, som i 1544 omdannedes til Universitet. Denne institutions primære opgave var at uddanne protestantiske præster, der talte de lokale sprog. Albrecht indførte endnu en nyhed: han stiftede stipendier og gav også byborgernes og bøndernes børn ret til at studere. Denne ret blev også tilkendt de indtil nu undertrykte oldpreussere. 


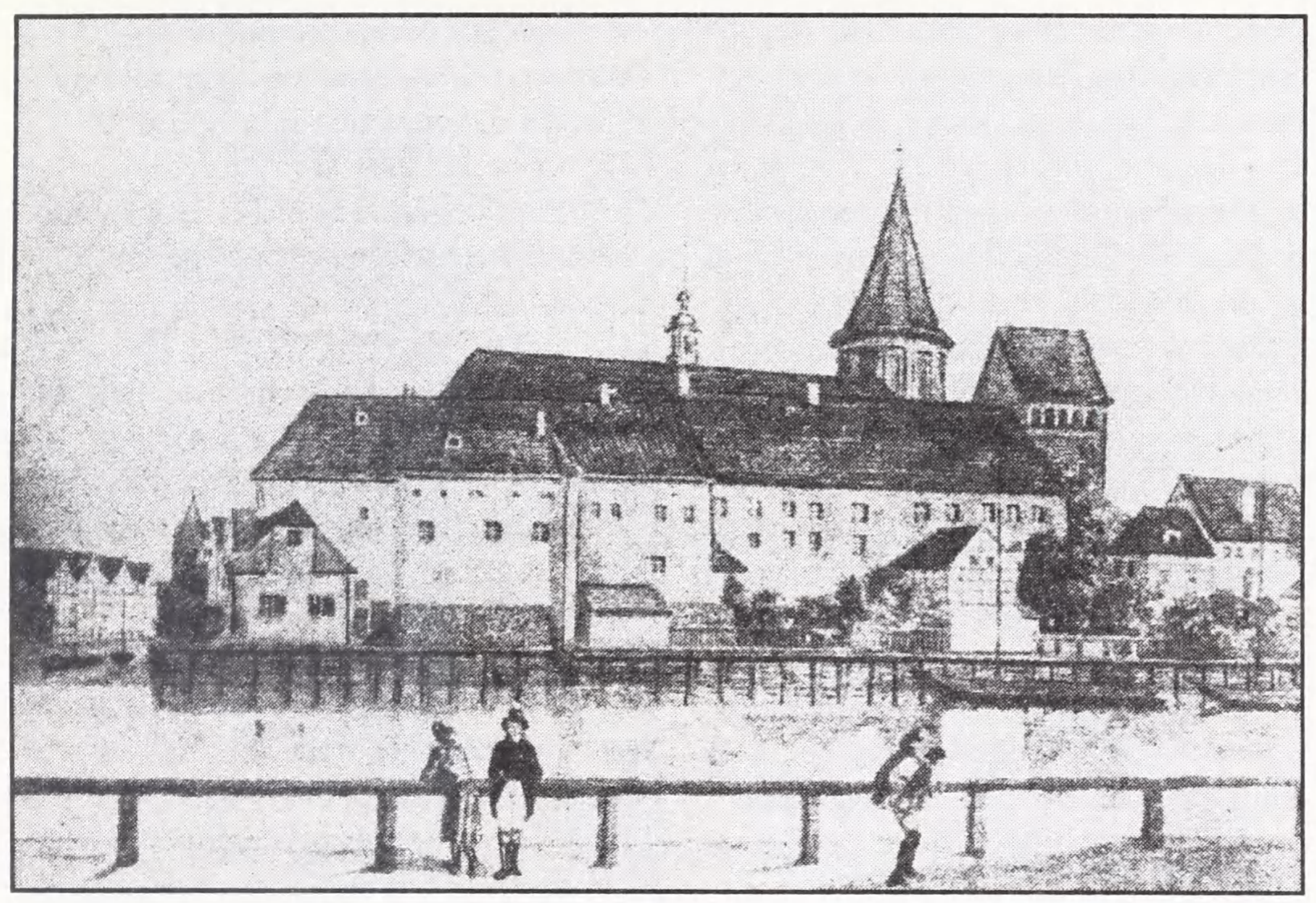

Det gamle Königsberg Universitet fra for 1861. Bag universitetet ses Königsbergs katedral, bvor bl.a. Immanuel Kant er begravet.

Universitet åbnede ikke kun døren for indbyggere i Østpreussen. Hertugen fik gennem kontakterne med nabolandenes adelsmænd tilsendt folk, som skulle missionere for den nye tro også i deres lande. Således kom en gruppe oplyste folk fra Litauen til Königsberg - i alt kendes 12 efternavne.

\section{Trykning af bøger bydes velkommen}

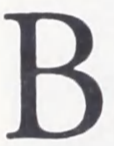
landt de litauiske studerende, som Albrecht personligt inviterede til Königsberg, var én, der hed Martynas Mazvydas Vaitkunas, immatrikuleret i Universitetets studenterregister i 1546 på latinsk som Martinus Masvidius.

Det er uvist, præcist hvor og hvornår M. Mazvydas blev født. Man gætter, at han sandsynligvis var født omkring 1520 i en byborgerfamilie. En dialektolo- gisk analyse af hans skrifter tillader at konkludere, at M. Mazvydas kommer fra Zemaitija, i det nuværende Silute distrikt (i Litauens sydvestlige del). Den unge mand kom til Königsberg efter at have studeret ved en skole, idet hertug Albrecht $i$ et af sine breve kalder ham eruditus. Udover modersmålet litauisk kunne M. Mazvydas også latin, polsk, gammelt hviderussisk (kancelli-slavisk) og sansynligvis oldgræsk. M. Mazvydas afsluttede Universitetet som bachelor på tre semestre i stedet for otte og udgav i denne utrolig korte periode en katekismus på litauisk - den første litauiske bog.

Han fandt et godt miljø i Königsberg. Her var Abraomas Kulvietis blevet leder af det Græske Institut ved Königsberg Universitet efter en mislykket luthersk mission i Vilnius. En anden litau- 
isk berømthed her var Stanislovas Rapolionis (Stanislaus Rapagelanus), leder af Universitetets Teologiske Institut. Begge professorer havde bl.a. oversat nogle af Luthers og andre protestanters skrifter samt salmer til litauisk og lagde således grunden til M. Mazvydas's litauiske skrifter. Königsberg Universitets rektor F. Staphylus har skrevet det latinske forord til M. Mazvydas's Katekismens ord, og selve hertug Albrecht støttede bogens udgivelse økonomisk.

At katekismen først og fremmest var udgivet til litauere i Storfyrstendømmet Litauen, ses ikke alene af forfatterens forsøg på at tilpasse sin (zemaitiske) dialekt til de højlitauiske (aukstaitiske) dialekter, som tales i de store områder vest for Siauliai, Kaunas og omkring Vilnius. Bogen starter med en latinsk dedikation til Storfyrstendømmet Litauen:

"Det lykkelige fædreland for de store regenter, dig, det berømte Litauen, modtag Guds ord med åbent hjerte..."

Bogens struktur afspejler forfatterens store ambitioner. Den første bog skulle være flere bøger i én. Dette ses af teksternes karakter. Udover katekismusen (M. Mazvydas benyttede sig af den polske protestant J. Seklucjans katekismer, J. Maleckys katekismus på polsk samt J. Willichs katekismus på latin) og salmer, som sandsynligvis ikke alene blev oversat af M. Mazvydas, men også af ovennærvnte A. Kulvietis og S. Rapolionis, samt to forord (inklusive det litauiske) og dedikationen, indeholder bogen også $\mathrm{ABCen}$.

Folk skulle jo lære at læse.

"Brødre og søstre, grib mig og læs!" E $\mathrm{n}$ af de mest interessante dele i bogen er dens litauiske forord, der består af 112 linier og er skrevet i vers (syntaktisk-intonationsmæssig versform). Det starter med følgende ord: "Brødre og søstre, grib mig og læs Og ved at læse prøv at forstå det! Jeres forældre ønskede meget denne viden, Men de kunne ikke få den på nogen måde..."

Dette giver umiddelbart indtryk af en række kedelige formaninger, skrevet på et gammeldags litauisk, som taltes i det 16 . århundrede: sproget, der stadigvæk indeholdt urgamle ordformer men samtidigt blev påvirket af nye idéer og begreber - alt det, der kom fra den store omverden og for første gang fik et verbalt udtryk. Dette var ikke nogen let opgave for forfatteren: man kan spore hans bestræbelser på at finde en rigtig sætningskonstruktion, et ord til et nyt begreb. Ordene lyder sommetider tunge og unaturlige og imponerer andre gange med deres fuldkommenhed. Nogle af de nydannede ord fra M. Mazvydas's skrifter kan man også finde i det moderne litauiske rigssprog.

Når man fordyber sig i indholdet af teksten, opstår et bredt panorama af religiøse og sociale forhold og skikke. Her

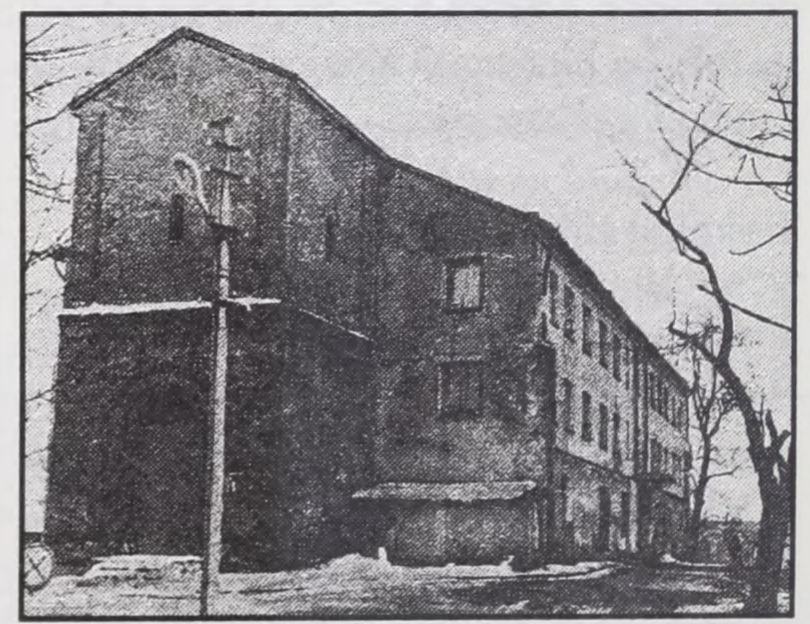

Kirken i Ragnit hvor Mazvydasarbejdede. Kirken blev odelagt under syvärskrigen men senere genopbygget. Foto fra 1987. 


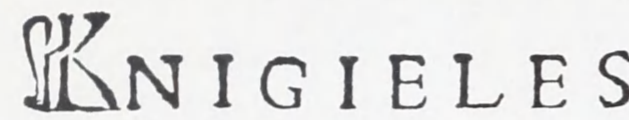

Pactise byla Leturuinttump ir

Escmatisiump.

13 zalei feferis imfict mani ir feaitflict Jreacal flaitioami permanifiet.

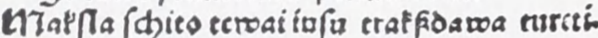

alle to migaleia ne wornu buou gautio

Eeglety to narela faroa atimis,

Taipyr ifthegirfi farua aufimis.

Jatz nu la teroai nalada neregieia/

tTu fobital wifo injump atcia.

Deisidtiet ir Oabaliecefe pimanes wy fas

Bd)itai cit ínfumpisabio bagaus paralifas

malanci ir fo dziaution ea fabi prigimtece

21 infu bultiufu fatermina makitice.

Sunus oulteris iufa tnr tatai matierts

Vifa fabyroy tur ta Dewa faoy milety.

Jcibralci feferis tus baojins mepapeitfie

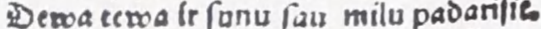

Ir pafchlawinti pa atimis ocwo bufice

Vifo fu dailte fo palaimi curefit.

Gdieu malflu derwa citrai pajylye

Jrougane teralificip prifiertyfye.
Tenferulke braled faperlf matte? Paitity Jelonater wales dema narir gimenty.

Jeitas fín menta giefme nar giedaty

mane po alimio faxa ear eurets.

Diena fir natri pres faxis mani lasililice

Ir nelada manes nog iufu nearmeferee.

Jei turfai mane nog fares atmis

Cofá newena pafitlo manip nogaus.

afd) falan ieg caifal $n$ ifooa enr tleiocty

Jrape fmeilata fawa netur nella finaty.

Enrfaf inenareto to matpla finacy ir matiety

Cafai amfinafo tampejo tur butf.

Cabrin ice Bmancfimanefp prifiartyntict

Irpagal to ft enta malfa gimentier.

Camfibes fenafes neg iuju fitualin atmantife

Bunus oufterio nog in ifd arielbefie

Jei ra maka Prilficsianiu malpa makiefit. Ir pagat fo tus potis faneredifit.

Zantus Esemeparis ir lautajargus pamep

Difas roelnumas ocinces apleiptet. (lices

Cos ocixes negat iuma nela eicta boty

beteur wylug amfinat prafulointy.

Emeilate wifue oialtas nog to ocma ta'

Zurío prifatimus coía manip regit. (rie.

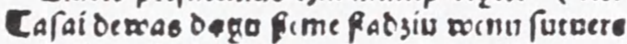

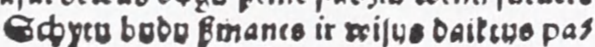
2 8 Dare.

Det litauiske forord hvori forfatterens navn er skjult i begyndelsesbogstaverne i linje 3 til 19.

udtrykker M. Mazvydas bogens formål "at erklære det nye, M. Luthers, ord og at plante det blandt litauerne, som stadigvæk tilbeder forkerte guder, foragter de evangeliske prædiker og overser Gud i julen, påsken og andre højtider" (fra M. Mazvydas's breve til hertug Albrecht).

Forordet er samtidig poesi, det første digt på litauisk. M. Mazvydas anvender her bl.a. en stilistisk figur, personificering: det er bogen selv, der henvender sig til læsere: "Brødre og søstre, grib mig og læs...", opfordrer dem til at modtage den "eneste rigtige tro" gennem selv at kunne læse og begribe verden. Således opnår de kedelige didaktiske formaninger farve, og den primære tanke om at plante den nye tro blandt folk bliver til et endnu mere ædelt formål: at lære folk at læse og føle behov for det trykte ord.

Citatet er blevet en poetisk kli- ché, som man genkender i litauisk litteratur siden slutningen af det 19 . århundrede - i mange forskellige forbindelser. Citatet er blevet symbol for national kultur.

Martinus Masvidius - Martynas Mazvydas

T lang tid - og indtil vores århundrede gættede man om, hvem der var forfatter til den første litauiske bog. Først i 1930'erne forstod den polske sprogforsker J. Safarewicz gåden: tredje til nittende linie i det litauiske forord i versene starter med bogstaver, som danner et forog efternavn på latin: Martinus Masvidius. Den måde, hvorpå M. Mazvydas officielt blev tiltalt.

Forfatterens ønske om ikke direkte at røbe sit navn var bevidst: hans bog var tilegnet en stor mission, ikke for at han skulle blive en berømt person. Man kan 


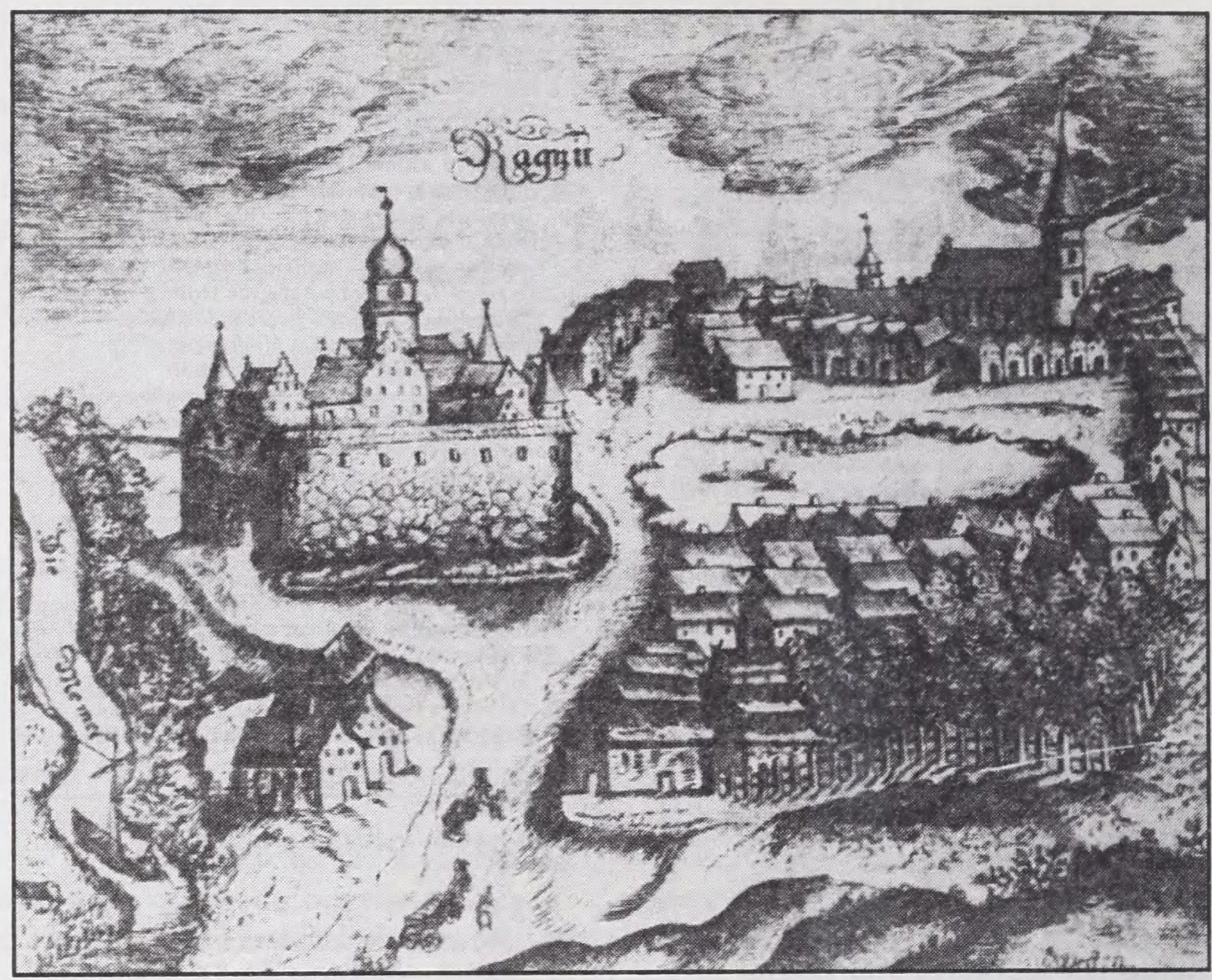

Ragnit $i$ begyndelsen af det 17. ärhundrede.I kirken til hojre arbejdede Mazvydas som prost.

klart se hans opfattelse i et forord til den senere udarbejdede salmebog (1. del 1566, 2. del 1570): “... Dette værk har jeg udført ikke for, at det i fremtiden bringer mit navn ære og berømthed. Jeg har gjort det for, at den litauiske Kirke med stort engagement og trofasthed herliggør navnet på den eneste Himmelske Guddommelige Far og Vores Herre Jesus Kristus, deres ære, storhed og dåd, og for, at vort modersmål bliver levende ved tjeneste og bliver videreført til vores efterkommere..."

Således var M. Mazvydas bevidst om og godt forberedt til de litauiske lutheraners historiske mission. Hans engagement endte ikke med én bog. Udover katekismen, har M. Mazvydas udarbejdet endnu fem religiøse bøger på litauisk: $A m$ brosius's og Augustinus's salmer (Giesmes $S$. Ambraseijaus bei Augustina. Königsberg. H. Weinreichs trykkeri, 1549), Dåbens form (Forma Chrikstima. Königsberg. J. Daubmans trykkeri, 1559), Kristelige salmer (Giesmes Chriksczoniskas. Königsberg. J. Daubmans trykkeri, 1566 og 1570) og Paraphrasis (Paraphrasis. Königsberg. G. Osterbergers trykkeri, 1589).

Formålet med M. Mazvydas's og hans landsmænds aktiviteter i Hertugdømmet Preussen var at forberede sig til missionering for den nye tro i Litauen. M. Mazvydas troede oprigtigt, at han kunne komme tilbage til et protestantisk Litauen. Det var dog skæbnens ironi, at han, lige- 


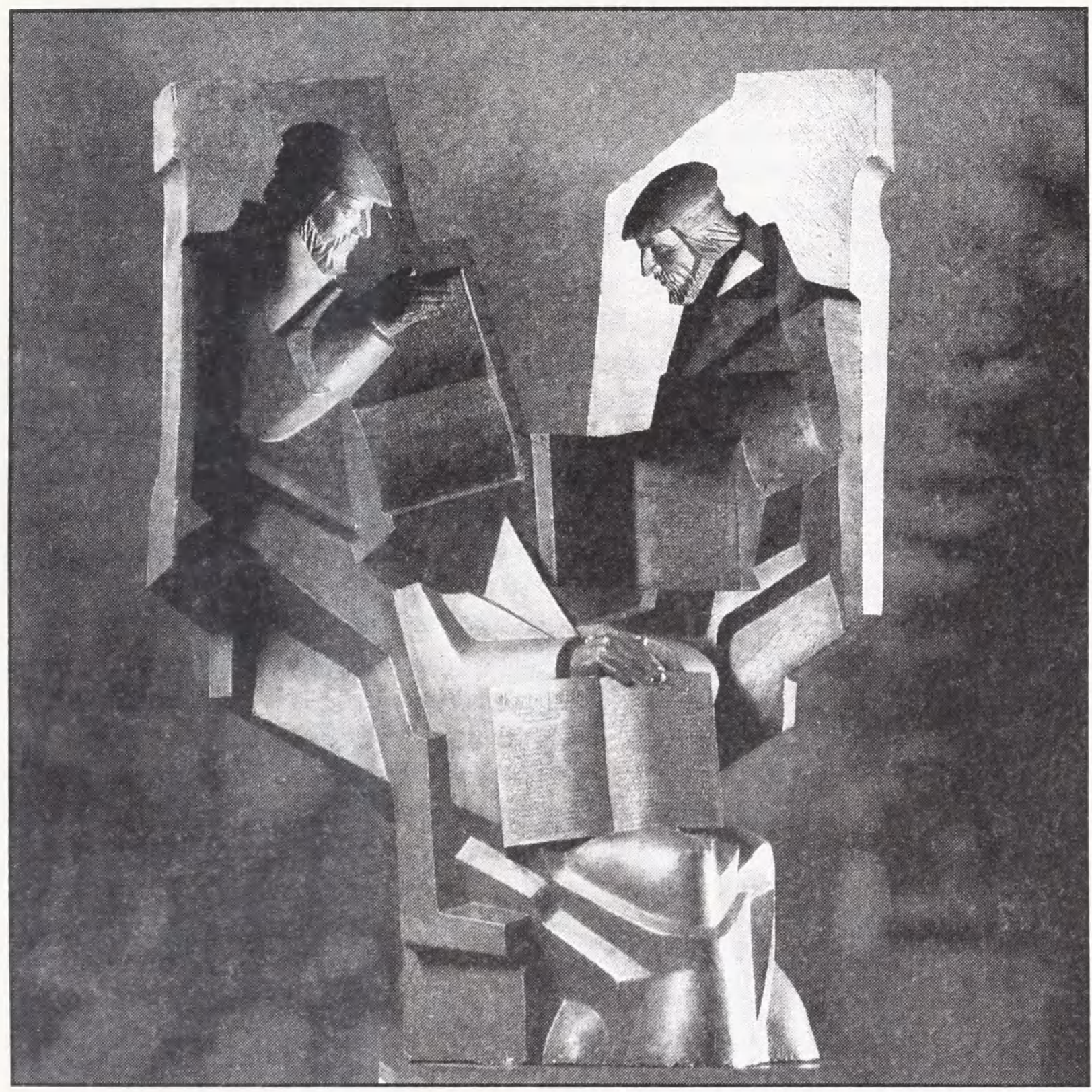

Moderne skulptur af Martynas Mazvydas fra 1980. Kunstneren er Midvikis. Ser man noje efter, er bogen i forgrunden släet op på katekismens forord. Se ill. s. 61.

som mange forfattere til de første litauiske bøger, trods dette blev boende i Østpreussen - på grund af religiøse opfattelser og hverdagsagtige forhold. M: Mazvydas fik stilling som sognepræst i Ragaine (eller Ragnit på tysk, nuværende Neman), hvor man hovedsageligt talte litauisk, og forglemte sig i hverdagslivets pligter og bekymringer for levebrødet.

Denne bortstrømning af intellektuelle var et stort tab for Litauen. På den anden side forberedte de oplyste folk, der var kommet fra Litauen, grundlaget for østpreussiske litaueres nationale og kulturelle aktiviteter. Jonas Bretkunas (1536-1602), som oversatte Biblen til litauisk, Danielius Kleinas (1609-1666), forfatteren til den første litauiske grammatik, Kristijonas Gotlibas Milkus (1732-1807), digter og filolog, Kristijonas Donelaitis (1714-1780), digter, og Ieva Simonaityte (1897-1978), forfatter, er kun nogle navne 
blandt mange berømte litteraturfolk, der kommer fra Østpreussen, eller det såkaldte Lille Litauen.

Derudover har M. Mazvydas's og andres aktiviteter tilskyndet til udgivelsen af litauiske bøger i selve Storfyrstendømmet Litauen. Vilnius, der først tabte til Königsberg hvad angår initiativ for udgivelse af bøger på nationale sprog og stiftelse af universiteter (Vilnius Universitet blev stiftet i 1579, altså ca. 30 år senere end Königsberg Universitet), forlod ikke sine kulturelle ambitioner, og i de senere århundreder foregik en direkte kulturel konkurrence mellem de to byer og de to lande, tilskyndet af den uafbrudte polemik mellem litauiske protestanter i Østpreussen og litauiske katolikker i Storfyrstendømmet Litauen.

\section{Forbud mod trykning af bøger}

$\mathrm{U}$ dgivelse af den første bog på litauisk var et vigtigt omdrejningspunkt i litauisk kultur. I stedet for håndskrevne tekster, som kun var tilgængelige for et begrænset antal personer, fik man nu mulighed for at udbrede sine idéer $i$ hundreder af kopier og bruge det trykte ord til mange formål.

Det interessante ved M. Mazvydas's Katekismus er, at bogen, som var udtryk for tidens ånd og middel til udbredelse af ny tro, har inspireret litauere i deres nationale bevægelse i den anden del af det 19. århundrede, hvor Litauen næsten et århundrede var indlemmet $\mathrm{i}$ det russiske imperium. I forbindelse med den af de russiske myndigheder gennemførte omfattende russificeringspolitik blev litauiske bøger forbudt (fra 1865 til 1904). Således kom udgivelsen af litauiske bøger igen til at blomstre i Østpreussen - især i byen Tilze (Tilsit på tysk, nuværende Sovetsk). Herfra indsmugledes bøger over floden Nemunas og udbredtes i Litauen. Denne gang var de trykt på initiativ af litauerne selv og uden de østpreussiske myndigheders støtte.

Det at udgive, indsmugle og læse forbudte bøger var en illegal og dermed meget farlig aktivitet. Alligevel blev hele nationen indblandet heri. Bøgerne blev et middel til udbredelse og styrkelse af national selvopfattelse, en form for national selvudfoldelse. Det var ikke blot litauernes reaktion på russificeringspolitikken. Det var også tegn på, at det af M. Mazvydas og andre forplantede litauiske ord stadigvæk var levende, - det voksede og blomstrede selv i landets sværeste tider.

Efter at Litauen havde genvundet sin uafhængighed i 1990, blev landets største bibliotek - Nationalbiblioteket omdøbt til M. Mazvydas's Nationale Bibliotek. Idag rummer biblioteket over 4,5 mio. bøger og andre udgivelser - resultatet af en stor udvikling siden 1547 - året for M. Mazvydas's litauiske bog.

Den vigtiste litteratur om M. Mazvydas's Katekismus:

A. Bezzenberger, Litauische und lettische Drücke des 16. Jahrbunderts. Bd. 1. Götingen, 1874.

G.B. Ford Jr, The Old Lithuanian Catechism of M. Mazvydas (1547), Assen, 1971.

M. Mazvydas, Katekizmas ir kiti raztai / Catechismus und andere Schriften, Vilnius: Baltos lankos, 1993.

Mosvid, Die ältesten litauischen Sprachdenkmäler bis zum Jahre 1570, Heidelberg, 1923.

J. Safarewicz, Un acrostiche de Mazvydas/ Prace filologiczne, t. 18, cz. 1, Warszawa, 1938.

Chr.S. Stang, Die Sprache des litauischen Katechismus von Mazvydas, Oslo, 1929. 